\title{
SYNTHESIS OF DNA AND MITOSIS IN RABBIT UTERI AFTER OESTROGEN AND PROGESTERONE INJECTIONS, AND DURING EARLY PREGNANCY
}

\author{
AUDREY E. LEE AND W. R. DUKELOW* \\ Department of Hormone Physiology, Imperial Cancer Research Fund, \\ Lincoln's Inn Fields, London WC2A 3PX, and Endocrine Research Unit, \\ Michigan State University, East Lansing, Michigan, U.S.A.
}

(Received 10th April 1972, accepted 21st June 1972)

In oestrogen-primed mice, progesterone stimulates stromal mitosis and inhibits epithelial mitosis (Finn \& Martin, 1967; Martin \& Finn, 1968). In rabbits, however, endometrial proliferation is stimulated by progesterone. This report describes DNA synthesis (measured by $\left[{ }^{3} \mathrm{H}\right]$ thymidine incorporation) and mitosis in the uterine epithelium of ovariectomized rabbits treated with oestrogen and progesterone, and in intact animals during early pregnancy.

Mature New Zealand White rabbits were given $5.0 \mathrm{mg}$ colchicine $(1.0$ $\mathrm{mg} / \mathrm{kg}$ body weight) in $1.0 \mathrm{ml}$ water intraperitoneally $6 \mathrm{hr}$ before death. The 'mitotic index' refers to the percentage of mitoses accumulated during this $6 \mathrm{hr}$ period. One hour before death, the rabbits were anaesthetized with sodium pentobarbitone and $100 \mu \mathrm{Ci}\left[{ }^{3} \mathrm{H}\right]$ methylthymidine (s.a. $20 \mathrm{Ci} / \mathrm{mmol}$, from New England Nuclear Corporation, Boston, Mass.) in $0.1 \mathrm{ml}$ saline was injected into the lumen of the left horn. The rabbits remained anaesthetized until they were killed. Portions of each injected horn were fixed in Bouin's solution. Autoradiographs were prepared using Kodak NTB2 emulsion, with 2 weeks' exposure at $4^{\circ} \mathrm{C}$. Results are the mean mitotic and labelling indices of each doe (two/group), counted in three microscope fields taken at random (800 to 1000 cells/uterus).

In the first experiment, rabbits were used 4 weeks after ovariectomy, and the injection schedule is shown in Table 1. Each hormone was injected subcutaneously in $0.1 \mathrm{ml}$ corn oil, and the does were killed $24 \mathrm{hr}$ after the last injection.

Table 1 and Pl. 1, Figs 1 and 2, show that oestrogen alone caused slight epithelial proliferation, whilst the stroma and myometrium remained atrophic even after 5 days' treatment. An additional doe killed 4 days after the last oestradiol injection showed a similarly low response.

Two injections of $0.5 \mathrm{mg}$ progesterone alone had no effect on the epithelium (Pl. 1, Fig. 3) although Hisaw, Greep \& Fevold (1937) and Gillman \& Stein

* Address for reprints: Dr W. R. Dukelow, Endocrine Research Unit, Michigan State University, East Lansing, Michigan 48823, U.S.A. 
(1942) found that progesterone would cause some proliferation without oestrogen pretreatment if a sufficiently large dose was given.

When oestrogen priming was followed by progesterone, maximal DNA synthesis and mitosis occurred after one or two daily injections of $0.5 \mathrm{mg}$ progesterone (Table 1, Pl. 1, Fig. 4). The response was similar to that seen on the 4th day of pregnancy. The mitotic and $\left[{ }^{3} \mathrm{H}\right]$ thymidine-labelling indices in the stroma were $2.9 \%$ and $6.3 \%$, respectively. In the circular muscle, the mitotic index was $3.5 \%$ and the labelling index $6.0 \%$ (Pl. 1, Fig. 5). Mitoses and labelled cells were rare in the longitudinal muscle.

The results suggest that priming with low doses of oestrogen lowers the threshold of the epithelial response to progesterone. The situation is the reverse of that in the mouse (Martin \& Finn, 1968; Lee, 1971), the rat (Clark, 1971) and the guinea-pig (S. Mehrotra and C. A. Finn, personal communication) where epithelial mitosis is induced by oestrogen and suppressed by progesterone.

\section{TABLE 1}

EFFECT OF OESTRADIOL AND PROGESTEMONE ON [ $\left.{ }^{3} \mathrm{H}\right]$ THYRIDINE INCORPORATION AND MITOSIS IN RABBIT UTERINE EPITHELIUM

\begin{tabular}{|c|c|c|c|c|c|c|c|c|c|c|c|}
\hline 1 & 2 & 3 & 4 & $\begin{array}{c}\text { Days } \\
5\end{array}$ & of tre & ment & 8 & 9 & 10 & $\begin{array}{c}{ }^{3} \mathrm{H} \text {-labelled } \\
\text { cells }\end{array}$ & $\%$ Mitoses \\
\hline $\begin{array}{l}\text { oe } \\
\text { oe } \\
\text { oe } \\
\text { oe } \\
\text { oe } \\
\text { oe }\end{array}$ & $\begin{array}{l}\frac{\text { oe }}{\text { oe }} \\
\text { oe } \\
\text { oe } \\
\text { oe }\end{array}$ & $\begin{array}{l}\frac{\text { oe }}{\text { oe }} \\
\text { oe } \\
\text { oe } \\
\text { oe }\end{array}$ & $\begin{array}{l}\frac{\text { oe }}{\text { oe }} \\
\text { oe } \\
\text { oe } \\
\text { oe }\end{array}$ & $\begin{array}{l}\frac{\text { oe }}{\text { oe }} \\
\text { oe } \\
\text { oe } \\
\text { oe }\end{array}$ & $\begin{array}{l}\overline{\text { oe }} \\
\text { oe } \\
\text { oe } \\
\text { oe }\end{array}$ & z & $\begin{array}{l}\mathbf{P} \\
\mathbf{P} \\
\mathbf{P} \\
\mathbf{P} \\
\mathbf{P}\end{array}$ & $\begin{array}{l}\mathbf{P} \\
\mathbf{P} \\
\mathbf{P}\end{array}$ & $\stackrel{P}{P}+O E$ & $\begin{array}{rr}0.5 ; & -1.0 \\
4.3 ; & 40 \\
0 ; & 0 \\
47 \cdot 0 ; & 17.7 \\
24.5 ; & 31 \cdot 0 \\
6.5 ; 2.2 \\
8.8 ; 15.6\end{array}$ & $\begin{array}{rr}0.2 ; & - \\
0.5 ; & 0.9 \\
0 ; & 0 \\
22.5 ; & 1.9 \\
21.9 ; & 11.7 \\
11.5 ; & 5.5 \\
4.8 ; & 0.7\end{array}$ \\
\hline
\end{tabular}

Does were killed $24 \mathrm{hr}$ after the last hormone injection, and $6 \mathrm{hr}$ after colchicine. Figures are the mean for each rabbit. oe $=2.5 \mu \mathrm{g}$ oestradiol; $P=0.5 \mathrm{mg}$ progesterone; $\mathrm{OE}=20.0 \mu \mathrm{g}$ oestradiol.

After a third injection of progesterone, cell proliferation decreased and this was also noticed in a subsequent experiment when four injections of progesterone were given. Although based on a very small sample, this result suggests that even with continuing hormonal stimulation, cell division in the epithelium does not proceed indefinitely but shows fluctuations in activity, as has been observed in the mouse (Lee, 1971).

\section{EXPLANATION OF PLATE 1}

All rabbits were killed $6 \mathrm{hr}$ after colchicine and $1 \mathrm{hr}$ after $\left[{ }^{3} \mathrm{H}\right]$ thymidine administration. All sections stained with $H \&$ E. $\times 320$.

Fig. 1. Uterus after a single injection of $2.5 \mu \mathrm{g}$ oestradiol.

Fig. 2. Uterus after $2.5 \mu \mathrm{g}$ oestradiol daily for 5 days.

Fig. 3. Uterus after $0.5 \mathrm{mg}$ progesterone daily for 2 days.

Fig. 4. Uterus after six daily injections of $2.5 \mu \mathrm{g}$ oestradiol followed by two daily injections of $0.5 \mathrm{mg}$ progesterone. There are numerous colchicine-arrested mitoses and $\left[{ }^{3} \mathrm{H}\right]-$ thymidine-labelled cells in the luminal epithelium and glands.

FIG. 5. Circular muscle from same rabbit as Fig. 4, showing mitoses and $\left[{ }^{3} \mathrm{H}\right]$ thymidinelabelled cells. 


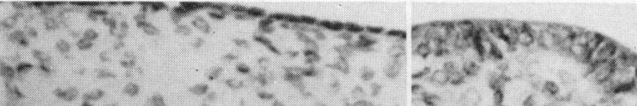

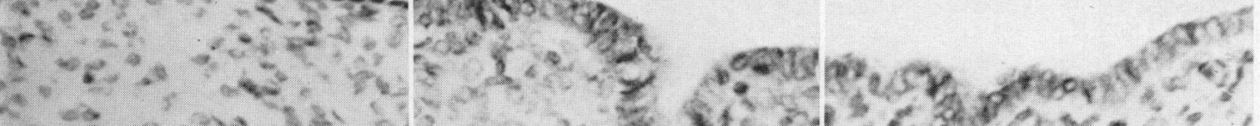

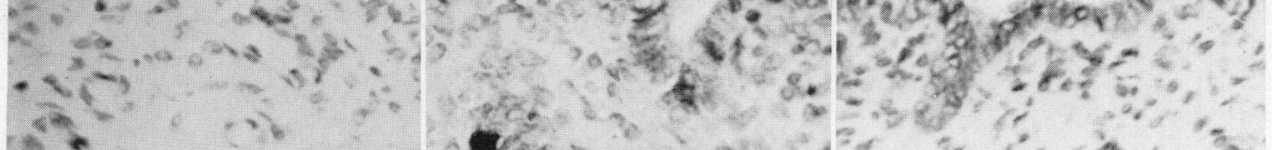

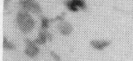

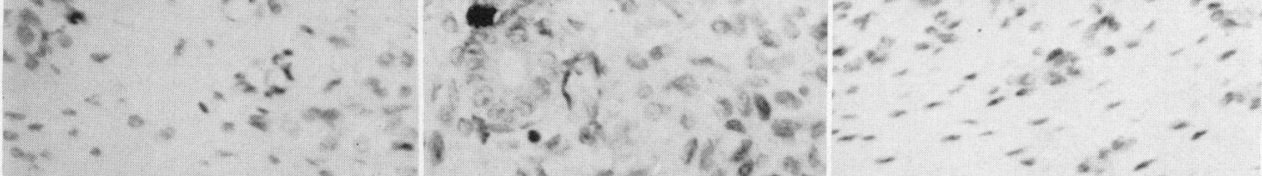

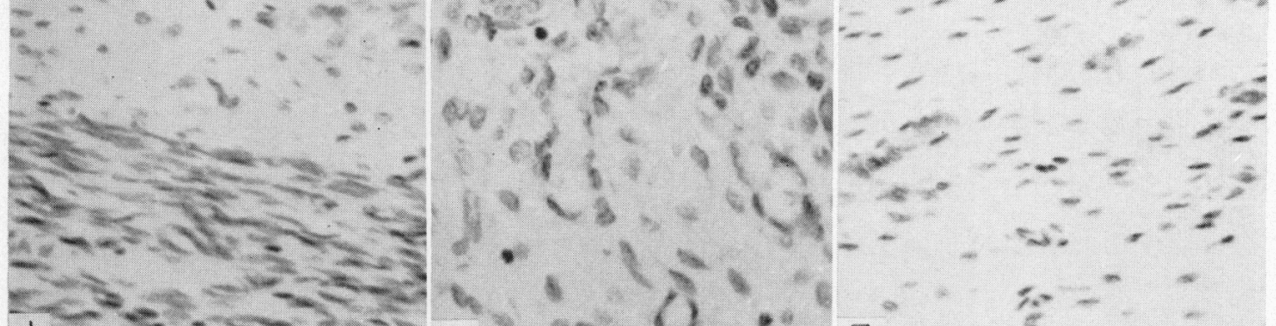

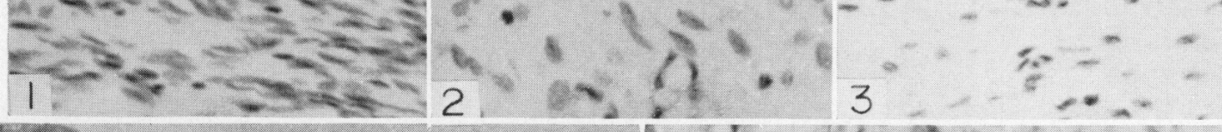

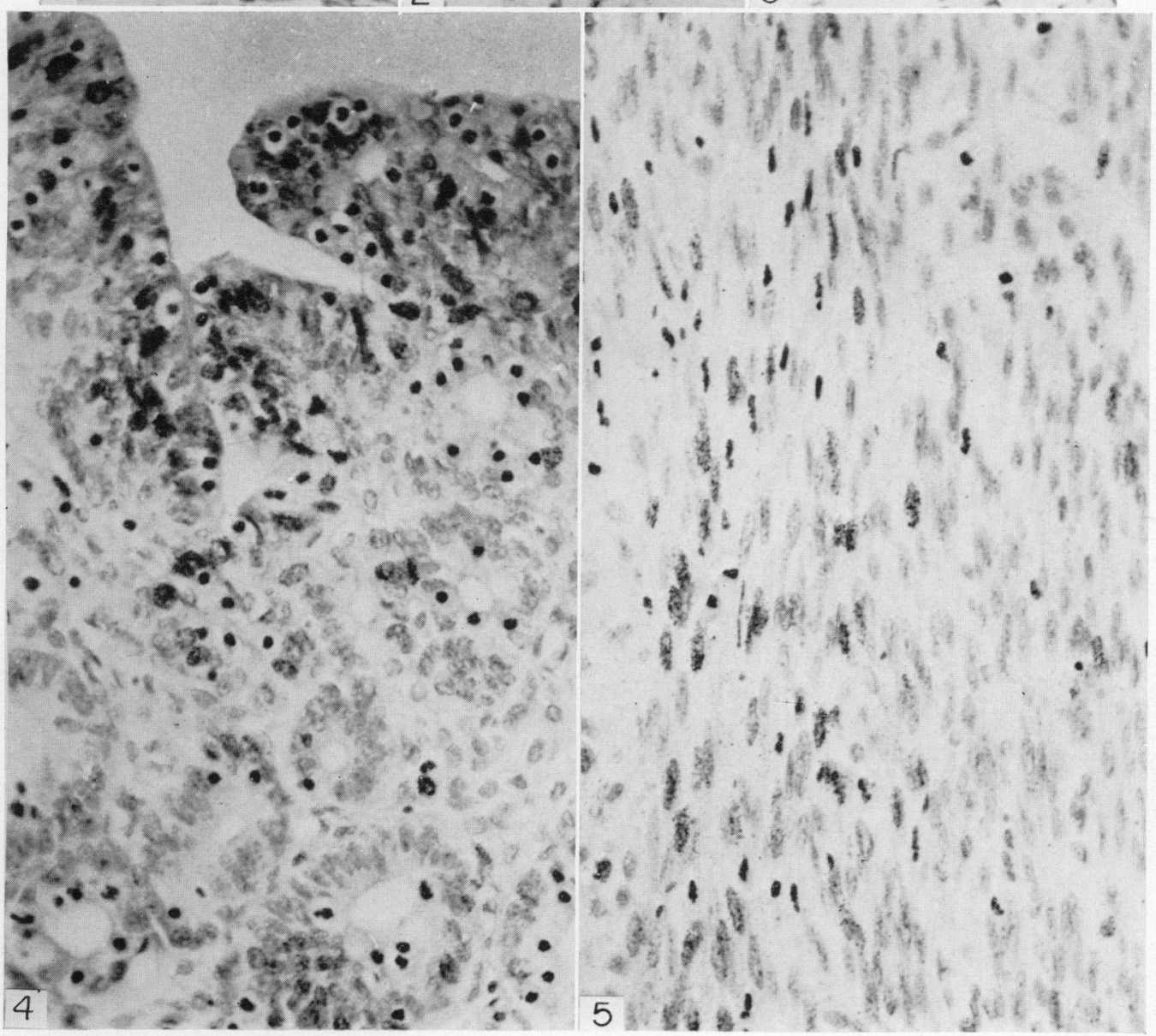

(Facing p. 474) 
A large dose of oestradiol given with the third injection of progesterone reduced mitosis, but not $\left[{ }^{3} \mathrm{H}\right]$ thymidine labelling. This was the same oestradiol:total progesterone ratio $(20 \mu \mathrm{g}: 1.5 \mathrm{mg})$ as that found by Courrier (1950) to prevent the formation of a progestational endometrium.

In the second experiment, females were given 100 units HCG intravenously at the time of mating (Day 1). Pregnancy was confirmed by inspection of the ovaries, and the oviducts were flushed with saline to detect ova or morulae. Table 2 shows that cell proliferation was highest on Days 3 and 4 of pregnancy, and then reverted to a low level. On Day 3 , there was some activity in the stroma $(3.6 \%$ mitoses, $6.4 \%$ labelled cells) and in the circular muscle $(1.9 \%$ mitoses, $4.3 \%$ labelled cells). On the other days, there was very little cell division in either stroma or muscle layers.

\section{TABLE 2}

INCORPORATION OF $\left[{ }^{3} \mathrm{H}\right.$ ]THYMIDINE AND MITOSIS IN RABBIT UTERINE EPITHELIUM DURING EARLY PREGNANCY

\begin{tabular}{|c|c|c|}
\hline Day of pregnancy & $\%^{3} H$-labelled cells & $\%$ Mitoses \\
\hline $\begin{array}{r}2 \\
3 \\
4 \\
5 \\
6 \\
7 \\
9 \\
10\end{array}$ & $\begin{array}{rr}0.3 ; & 16.6 \\
32.5 ; & 33.1 \\
27.4 ; & - \\
7.0 ; & 3.9 \\
3.0 ; & 0.4 \\
0.3 ; & - \\
0.4 ; & 0.9 \\
- & -\end{array}$ & $\begin{array}{rr}2 \cdot 6 ; & 0 \\
21 \cdot 6 ; 20.5 \\
17 \cdot 2 ; 25.5 \\
4 \cdot 6 ; 2.7 \\
0.3 ; & 0 \\
0.1 ; & - \\
0.1 ; & 0.2 \\
0.8 ; & 3.0\end{array}$ \\
\hline
\end{tabular}

Animals were killed $6 \mathrm{hr}$ after colchicine. Figures are the mean for each rabbit.

In rabbits, there is a short preovulatory release of $20 \alpha$-hydroxypregn-3-en-4one (Eaton \& Hilliard, 1971) from the interstitial tissue of the ovary (Hilliard, Archibald \& Sawyer, 1963) immediately after mating. The results in Table 1 suggest that this progestin surge is important in the stimulation of the endometrial proliferation seen on Days 3 and 4 of pregnancy. Hafez \& Pincus (1956) found that oestrogen was not necessary for implantation in the rabbit, and Greenwald (1963) reported that oestradiol cyclopentyl-propionate injected immediately after mating, delayed endometrial proliferation. After the initial secretion of interstitial progestin, luteal progestin increases steadily during the first half of pregnancy (Zarrow \& Neher, 1955; Mikhail, Noall \& Allen, 1961; Eaton \& Hilliard, 1971) but in spite of this, cell division remains at a low level from Days 6 to 10, which is in accordance with the decrease previously observed after several injections of progesterone.

We would like to thank Dr L. Martin, Imperial Cancer Research Fund, for his suggestions and advice and Dr B. E. Walker, Department of Anatomy, Michigan State University for the use of autoradiography facilities.

This work was supported by USPHS Grant No. 5-P06-RR-00366-04 and NIH Research Career Development Award 1-K04-HD35306-01. Journal 
Article No. 5918, Michigan Agricultural Experiment Station, Michigan State University.

\section{REFERENCES}

CiLARK, B. F. (1971) The effect of oestrogen and progesterone on uterine cell division and epithelial morphology in spayed, adrenalectomized rats. F. Endocr. 50, 527.

CourRIER, R. (1950) Interactions between oestrogens and progesterone. Vitams Horm. 8, 179.

Eaton, L. W. \& Hilliard, J. (1971) Estradiol-17 $\beta$ and progestin released by the rabbit ovary from mating through implantation. Biol. Reprod. 5, 89.

Finn, C. A. \& MARTin, L. (1967) Patterns of cell division in the mouse uterus during early pregnancy. 7. Endocr. 39, 593.

Gillman, J. \& Stein, H. B. (1942) Quantitative study of antagonism of estrogen and progesterone in castrate rabbit. Endocrinology, 31, 167.

GREENWALD, G. S. (1963) Interruption of early pregnancy in the rabbit by a single injection of oestradiol cyclopentylpropionate. F. Endocr. 26, 133.

Hafez, E. S. E. \& Pincus, G. (1956) Hormonal requirements of implantation in the rabbit. Proc. Soc. exp. Biol. Med. 91, 531 .

Hilliard, J., ARchibald, D. \& Sawyer, C. H. (1963) Gonadotrophic activation of preovulatory synthesis and release of progestin in the rabbit. Endocrinology, 72, 59.

Hisaw, F. L., Greep, R. O. \& Fevold, H. L. (1937) Effects of progesterone on the female genital tract after castration atrophy. Proc. Soc. exp. Biol. Med. 36, 840.

LEE, A. E. (1971) The effect of continuous oestrogen on mitosis and $\left[{ }^{3} \mathrm{H}\right]$ thymidine incorporation in the mouse uterus. In: Basic Actions of Sex Steroids on Target Organs, p. 243. Eds. P. O. Hubinont, F. Leroy and P. Galand. Karger, Basel.

Martin, L. \& Fins, G. A. (1968) Hormonal regulation of cell division in epithelial and connective tissues of the mouse uterus. F. Endocr. 41, 363.

Mrkhail, G., Noall, M. W. \& Allen, W. M. (1961) Progesterone levels in the rabbit ovarian vein blood throughout pregnancy. Endocrinology, 69, 504.

Zarrow, M. X. \& Neher, G. M. (1955) Concentration of progestin in the serum of the rabbit during pregnancy, the puerperium and following castration. Endocrinology, 56, 1. 